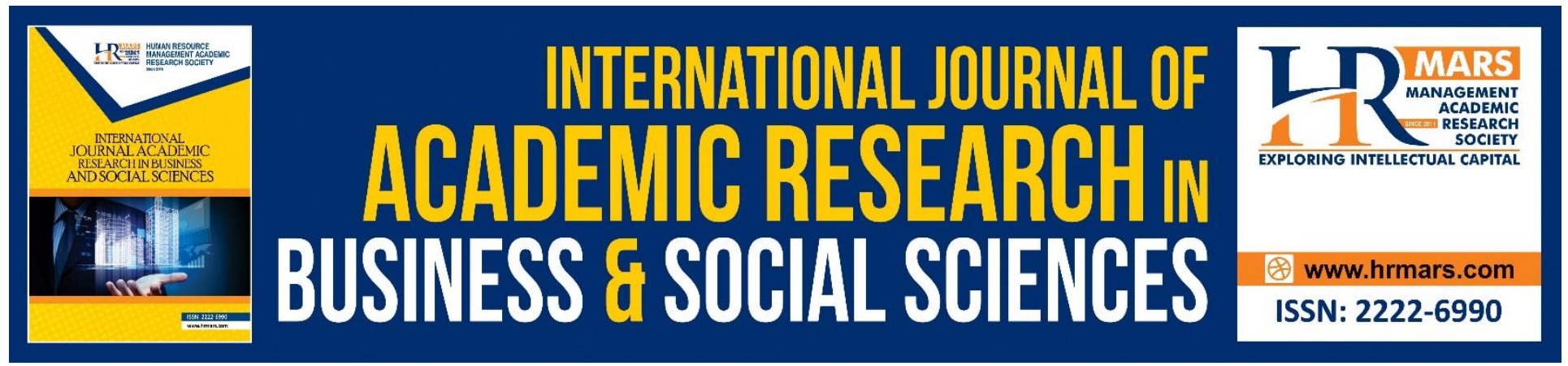

\title{
Interpretation of Cultural and Environmental Issue as a Theme in Malaysian Contemporary Painting Since 1960
}

Shahariah binti Mohamed Roshdi, Abd Rasid bin Ismail, Mohd Haniff bin Mohd Khalid, Azahar bin Harun, Nor Syuhada binti Ahmahrashidi and Siti Nur Aliah binti Abd. Rasid

To Link this Article: http://dx.doi.org/10.6007/IJARBSS/v8-i11/4949

DOI: $10.6007 /$ IJARBSS/v8-i11/4949

Received: 13 Oct 2018, Revised: 08 Nov 2018, Accepted: 26 Nov 2018

Published Online: 06 Dec 2018

In-Text Citation: (Roshdi et al., 2018)

To Cite this Article: Roshdi, S. binti M., Ismail, A. R. bin, Khalid, M. H. bin M., Harun, A. bin, Ahmahrashidi, N. S. binti, \& Rasid, S. N. A. binti A. (2018). Interpretation of Cultural and Environmental Issue as a Theme in Malaysian Contemporary Painting Since 1960. International Journal of Academic Research in Business and Social Sciences, 8(11), 722-732.

Copyright: (C) 2018 The Author(s)

Published by Human Resource Management Academic Research Society (www.hrmars.com)

This article is published under the Creative Commons Attribution (CC BY 4.0) license. Anyone may reproduce, distribute, translate and create derivative works of this article (for both commercial and non-commercial purposes), subject to full attribution to the original publication and authors. The full terms of this license may be seen

at: http://creativecommons.org/licences/by/4.0/legalcode

Vol. 8, No. 11, 2018, Pg. 722 - 732

http://hrmars.com/index.php/pages/detail/IJARBSS

JOURNAL HOMEPAGE

Full Terms \& Conditions of access and use can be found at http://hrmars.com/index.php/pages/detail/publication-ethics 


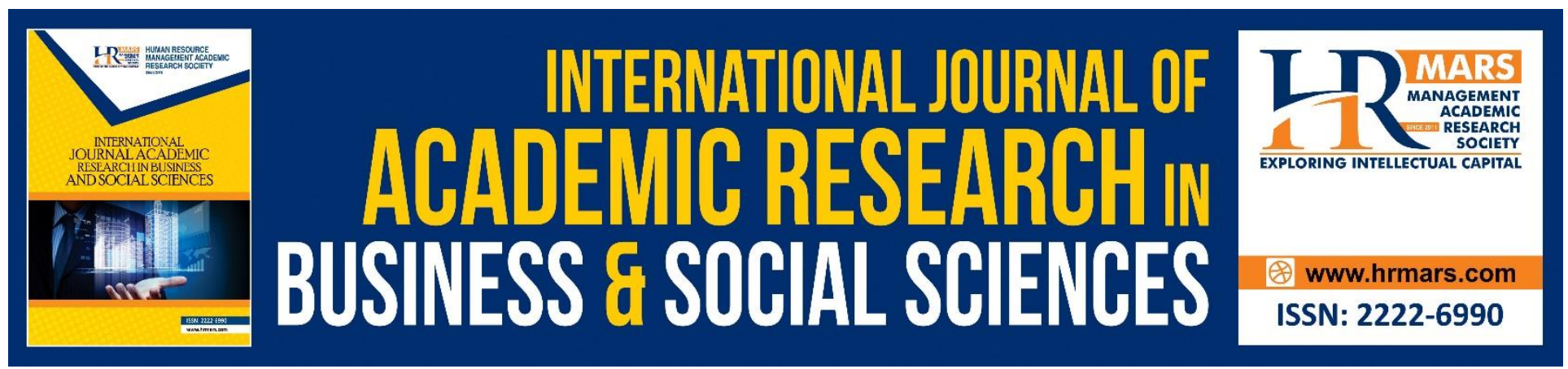

\title{
Interpretation of Cultural and Environmental Issue as a Theme in Malaysian Contemporary Painting Since 1960
}

\author{
Shahariah binti Mohamed Roshdi ${ }^{1}$, Abd Rasid bin Ismail ${ }^{2}$, Mohd \\ Haniff bin Mohd Khalid ${ }^{3}$, Azahar bin Harun ${ }^{4}$, Nor Syuhada binti \\ Ahmahrashidi ${ }^{5}$ and Siti Nur Aliah binti Abd. Rasid 6 \\ $1 \& 2$ Faculty of Arts and Design, Universiti Teknologi MARA Melaka, Malaysia \\ ${ }^{3}$ EPF Learning Campus, Malaysia \\ ${ }^{4}$ Faculty of Arts and Design, Universiti Teknologi MARA Melaka, Malaysia \\ ${ }^{5}$ Faculty of Communication and Media Studies, Universiti Teknologi MARA Shah Alam, Malaysia \\ ${ }^{6}$ Faculty of Communication and Media Studies, Universiti Teknologi MARA Negeri Sembilan, \\ Malaysia
}

\begin{abstract}
The study of local paintings has been around for a long time and the finding says most of the time, the environment is the main subject matter as source of inspiration. However, only a few researches are being made on the implicit meaning of paintings. In Malaysia since the 90s, environmental themes have declined and rarely seen in records and even so there is some, the finding is not so consistent. Paintings that usually uses landscapes or environmental characteristic as a primary focus, shows the atmosphere of local surroundings and cultural heritage. This study was aimed at analysing the artistic foundations in the paint that emphasized the cultural and environment. This paper discuss about how to interpret the cultural elements and environmental theme that is used and embedded inside the contemporary paintings that is presented in the Malaysian local art scene from the year 1960 until 2016. The theme of local culture and environmental activities often becomes a subject matter for the artist to make a documentation of it with their paintings. The research on contemporary painting in Malaysia was studied for publishing analytical data holistically. Research through visual observation based on a certain art theory is used to obtain data on cultural and artistic environment through observations of multiple artworks. Through this study, the artworks have been used as the primary medium to help the society to better understand and appreciate the aesthetic values of environmental and cultural elements in more elaborate detail. Cultural and environment also bring meaning that relies on current changes affecting heritage and tradition. Through contemporary
\end{abstract}


INTERNATIONAL JOURNAL OF ACADEMIC RESEARCH IN BUSINESS AND SOCIAL SCIENCES

Vol. 8, No. 11, Nov, 2018, E-ISSN: 2222-6990 @ 2018 HRMARS

artworks characterized by cultural heritage should be preserved as it symbolizes the uniqueness and the identity of Malaysia.

Keywords: Culture, Environment, Fundamental, Contemporary Paintings, Art Analysis

\section{Background Study}

The art of painting appears as an expression of the artist's imagination towards appreciating nature. Ancient paintings made by earlier generation of humans who resides within Tambun Cave, Perak and in Niah Cave, Sarawak proved that most of early artistic ideas came from the environment at that time. Animal and plants are being used as the primary subject matter and their painting tells the story of how the environment interacts with their daily activities. Paintings on the surface of the walls are related to the religious beliefs of indigenous peoples in the region. To date, spiritual disparities are still appearing in the form of sketches and scratches on the walls of the cave and have a meaningful effect primarily on the formation of symbolic images which are the most important historical facts in Malaysia (Liz Price, 2014). The symbol depicts the development of thought as a cultural relationship, so the painter is often called upon to interpret the surroundings into a creative art product that contains ideas and inspiration from the environment. These elements have always been inviting responses from many artists especially during the British involvement politics within Malaya which began in Penang in 1786 (Muliyadi Mahamood, 2004)

The involvement of the British in administrative affairs reflects their efforts to change the sociocultural situation of the country, and this situation can be described as the basis of the emergence of modern Malaysians (Andaya, Barbara Watson, 1983). A study of cultural and environmental changes is seen in detail by highlighting important events illustrated through the work of paintings in Malaysia (Redza Piyadasa, 1981). Environmental engagements and forms of cultural change remain the major subjects that are so popular but are characterized by challenges coming in through different angles.

This research will highlight some of the differences in views on the paintings in Malaysia which are facing challenges in reviewing the changes that occurs in our surrounding. Reviews of an exhibition titled MATAHATI - For Your Pleasure: Signifikasi Catan di Malaysia? by Safrizal Shahir (2008), in his article he questions the local scope of the paintings that embodied the basic issues such as the position of the paintings, the language paintings or the context of the paintings.

According to T.K Sabapathy and Redza Piyadasa (1983) the usage of environmental themes for example can be traced through the work of Pago Pago's painting series by Abdul Latiff Mohidin who appeared in the mid-60s. He favors the form of primitive art and chooses some form of regional cultures that are processed into certain aspects of the local scene. Latiff's approach to German Expressionism is based on the conjunctions of plants and insects. In addition, the work of Abdullah Arif also features paintings that surrounds the environmental theme that relates to resources or income. His work entitled Happy Earth's Malayan Mine produced in the 1960s used spontaneous brush sweeping and washing techniques to illustrate the country's revenue (Muliyadi Mahamood, 2004). In an essay on the Exhibition of Local Landscape Processing in Modern Malaysian Art 1930 1981, Redza Piyadasa (1981) states Malaysia is facing a challenge to "study sincerely the changes that have always been happening around us. The future of the country's art industry looks only as a meaningful activity if it is based on a sincere view and feeling". 
In 1971, the National Cultural Congress was established in Kuala Lumpur. Based on the fundamental concepts that became the basis of national culture, many changed the spirit and the position of the painter and influenced the style in the local art within the decade. The congress provides a clear guideline on the perspective of the country's identity. Three important concepts that form the basis of National Culture. First of all it should be based on the native culture of the people of this region. Secondly, other cultural elements that are appropriate and deserving to be accepted into national cultural elements. Third, Islam is an important element in the formation of the national culture (Azian Tahir, 2009). Through the basic concept of national culture it can be concluded that the foundation has provided a foundation full of pure values in shaping the minds of artists.

Malaysian artists have been affected by their realisation of the degradation of environmental qualities since the last thirty years. Since the 1990s, there are artists who have been very critical. The landscape and environment are not the idealized subject anymore but as a way for them to convey their astute or critical observations on what is happening in Malaysia, especially on issues pertaining to the indirect result of a deteriorating environment and quality of nature in general (Sarena Abdullah, 2012)

This research is for analyse the basic art elements towards the element of culture and surroundings that exist in Malaysian paintings. Observation materials will be consisting of five samples of paintings. This study will see the development of contemporary paintings in Malaysia around 1960 to 2016.

\section{Research Methodology}

This study uses qualitative methods. In term of collecting data, the observation method is much more suitable in providing a systematic overview of the events and environments found in the study sample.

The theory posed by Edmund Feldman (1994) and Rosalind Ragan (2005) is used because of their approach in using criticism in interpreting an artwork in detail. As mentioned by Abd Rasid Ismail (2014) the elements and features within paintings are difficult to analyse without any proper measurement instrument or tool. A method introduced by Ragan (2005) that is called Aesthetic Evaluation Method use four steps of art criticism that helps to analyse the artistic foundation within a painting. Another method that is introduced by Feldman (1994) puts four major disciplines in criticism that is describing, analyzing facts, interpreting and evaluating. Scientific criticism typically uses multiple systematic theoretical and methodological approaches, focusing on the target, having a structured schedule and having a sufficient amount of time. This type of criticism will often be used as a source of academic and scientific references on an ongoing basis (Feldman, 1994). 
INTERNATIONAL JOURNAL OF ACADEMIC RESEARCH IN BUSINESS AND SOCIAL SCIENCES Vol. 8, No. 11, Nov, 2018, E-ISSN: 2222-6990 @ 2018 HRMARS

Referring to Ragan's theory, the analysis can be done by using the following structure:

\begin{tabular}{|l|l|}
\hline Ragan's Theory & $\begin{array}{l}\text { Through the sample, description can clarify } \\
\text { the background of the painter, the year it } \\
\text { was produced, the sample size and the } \\
\text { medium that is used within the painting. }\end{array}$ \\
\hline How is the work organized? & $\begin{array}{l}\text { Analyzing sample with detail to obtain the } \\
\text { data from the characteristic within the } \\
\text { elements that is used. }\end{array}$ \\
\hline $\begin{array}{l}\text { What is the message that the } \\
\text { work is trying to convey? }\end{array}$ & $\begin{array}{l}\text { Interpreted the elements used within the } \\
\text { sample in giving meaning about the } \\
\text { surrounding within Malaysia or any cultural } \\
\text { values. }\end{array}$ \\
\hline Is this work successful? & $\begin{array}{l}\text { Evaluate samples through the images } \\
\text { contained in them by describing critical } \\
\text { issues of culture and environment. }\end{array}$ \\
\hline
\end{tabular}

This study also uses the Art Criticism system method introduced by Edmund Feldman's theory. Interpretation is tremendously challenging; it is certainly the most important part of the critical enterprise. Explaining a work of art involves discovering its meanings and also starting the relevance of these meanings to our lives and to the human situation in general (Edmund Feldman, 1994). Painting on the theme of cultural and environmental has a significance way to explain something. The significance can be unveiled by using the art critics method theory is introduced by Edmund Feldman.

The Feldman system of criticism (Feldman's Critical System) is a process of general conclusions based on the features available. The model of criticism has four levels to make a statement about a work. It has been used by educators in art appreciation as the basis for students to understand this technique and can thus think and talk about art more deeply. According to Maithreyi Subramaniam, Jaffri Hanafi and Abu Talib Putih (2016), Feldman believes that this technique can help students more interest and better understand art. Discussion is one of the important components of experiencing and interpreting a work. Here is the Feldman Critical System often used by students to criticize artwork:

Sample of contemporary artwork used as a test material consists of five (5) pieces produced by Abdul Latiff Mohidin, Chuah Thean Theng Ismail Mat Hussin, Abu Bakar Idris and Jalaini Abu Hasan.

\begin{tabular}{|l|l|}
\hline \multicolumn{2}{|c|}{ Feldman' Art Critics System } \\
\hline & Description: \\
& Artist: Abdul Latiff Mohidin. \\
& Title: Pago Pago Landscape. \\
& Medium: oil on canvas \\
& Size: $40 \times 39 "$. \\
& Year: 1967 \\
\hline
\end{tabular}




\begin{tabular}{|l|l|}
\hline $\begin{array}{l}\text { Sample A } \\
\text { Picture Source : }\end{array}$ & $\begin{array}{l}\text { Analysis: Shows the appearance of a } \\
\text { biomorphic characterized } \\
\text { pattern of flora or fauna. Using the expression } \\
\text { / style expressionist. The use of warm and cold } \\
\text { colours is almost balanced on the whole of the } \\
\text { paint. }\end{array}$ \\
\hline Modern Artist of & $\begin{array}{l}\text { Interpretation: Identified primitive formation } \\
\text { identified. The expression of vegetables and } \\
\text { Malaysia,T.KSabapathy / Redza } \\
\text { Piyadasa,1983 }\end{array}$ \\
& $\begin{array}{l}\text { Assess: Image looks united with nature. The } \\
\text { originated from Southeast Asia. } \\
\text { merging of environmental ideas is embedded } \\
\text { through the forms of plants and insects. There } \\
\text { are primitive artistic values as well as cultural } \\
\text { features that are organized into a local } \\
\text { atmosphere. }\end{array}$ \\
\hline
\end{tabular}

Figure 1: Data analysis of Sample A

\begin{tabular}{|c|c|}
\hline \multicolumn{2}{|c|}{ Feldman' Art Critics System } \\
\hline$+\frac{10}{20}$ & $\begin{array}{l}\text { Description: } \\
\text { Artist: ChuahThean Theng } \\
\text { Title: Mother and children with origami } \\
\text { bird. } \\
\text { Medium: Batik } \\
\text { Size: } 43.5 \mathrm{~cm} \times 58.5 \mathrm{~cm} \\
\text { Year: } 1969 \text {. }\end{array}$ \\
\hline $\begin{array}{l}\text { PIcture source: } \\
\text { https://www.mutualart.com/Artwork/Mother- } \\
\begin{array}{l}\text { and-Children-with-Origami- } \\
\text { Bird/EAAA2253EA955F77 }\end{array}\end{array}$ & $\begin{array}{l}\text { Analysis: The figures resembles the } \\
\text { character of the mother, the girl and } \\
\text { the baby. The large size of the figure } \\
\text { and light becomes the focus of } \\
\text { emphasis in the centre of the field. } \\
\text { Elements of fauna origami shapes held } \\
\text { by the child. }\end{array}$ \\
\hline & $\begin{array}{l}\text { Interpretation: The white flower image } \\
\text { on the lower left side of the work } \\
\text { demonstrates a comfortable and safe } \\
\text { atmosphere. Two strands of banana } \\
\text { leaves represent the symbol of a source } \\
\text { of sustenance outside the city. } \\
\text { The banana leaves reminds the } \\
\text { audience of nasi lemak, pisang banana, } \\
\text { cekodok, pengat and so on. Woven }\end{array}$ \\
\hline
\end{tabular}




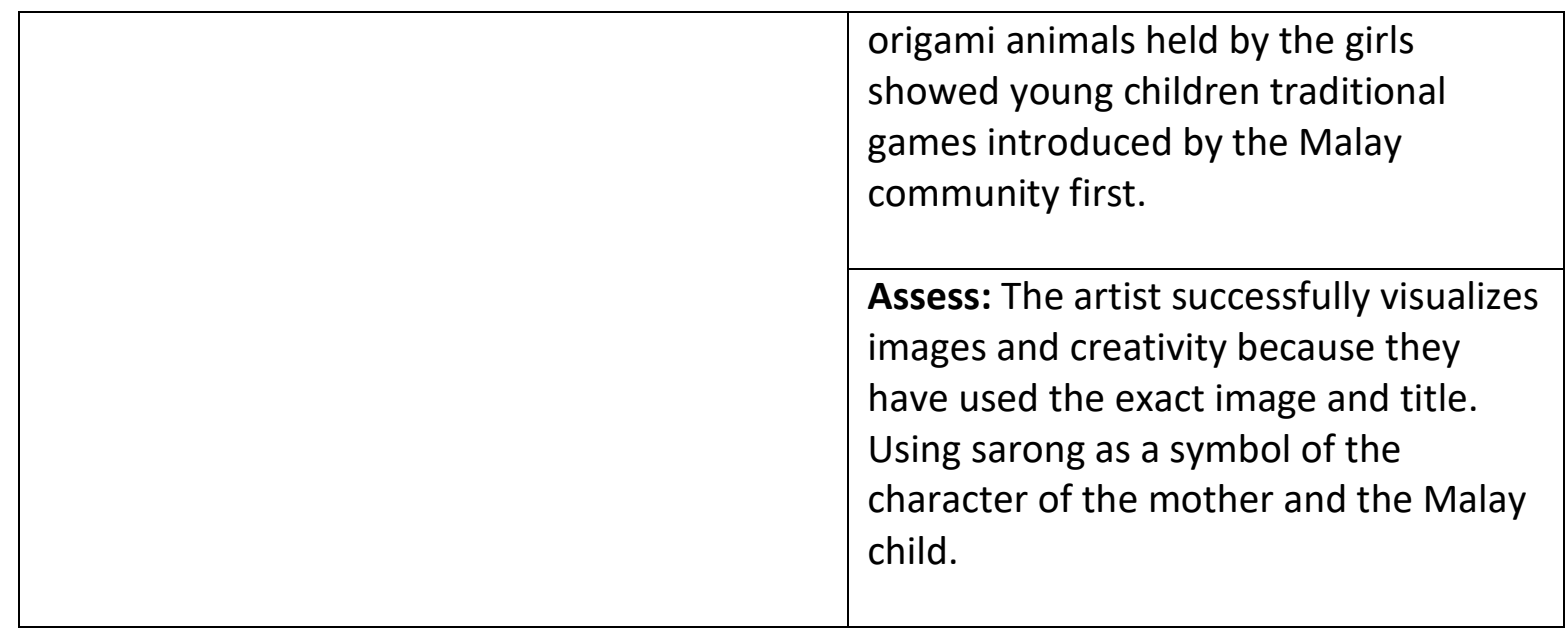

Figure 2: Data analysis of Sample B

\begin{tabular}{|l|l|}
\hline \multicolumn{2}{|c|}{ Feldman' Art Critics System } \\
\hline \multirow{2}{*}{$\begin{array}{l}\text { Sample C } \\
\text { Picture Source: }\end{array}$} \\
$\begin{array}{l}\text { Description: } \\
\text { Artist: Ismail Mat Hussin } \\
\text { Title: Early / Mid 1990s Father and Son with } \\
\text { Fighting Fish } \\
\text { Medium: Batik } \\
\text { Size: 45cm x 45cm. } \\
\text { Year: } 2002 .\end{array}$ \\
$\begin{array}{l}\text { Analysis: Line elements that highlight each image. } \\
\text { Most of the images are dominated by } 2 \text { image } \\
\text { figures and 2 large bottles compared to other } \\
\text { images. Use a matching brown color. The focus of } \\
\text { this batik work can be seen through the } \\
\text { composition of } 2 \text { fig trees that look towards } 2 \\
\text { bottles. }\end{array}$ \\
\hline $\begin{array}{l}\text { Interpretation: The image used as the emblem of } \\
\text { the Malay children's traditional game of the game } \\
\text { is a game of fish. The moody work mood can be } \\
\text { seen through the use of hot chocolate colors. The } \\
\text { atmosphere seems to appeal to the past memories } \\
\text { of a painter who looks more nostalgic. The artist } \\
\text { expresses creativity by placing elements of } \\
\text { movement lines for action on the figure. }\end{array}$ \\
$\begin{array}{l}\text { Assess: Images of objects, and fish in a vertical } \\
\text { composition is a bit boring. The use of a fish is a } \\
\text { subject of an environment that is designated as a } \\
\text { local entertainment culture. }\end{array}$ \\
\hline
\end{tabular}

Figure 3: Data analysis of Sample C 


\begin{tabular}{|c|c|}
\hline \multicolumn{2}{|c|}{ Feldman' Art Critics System } \\
\hline 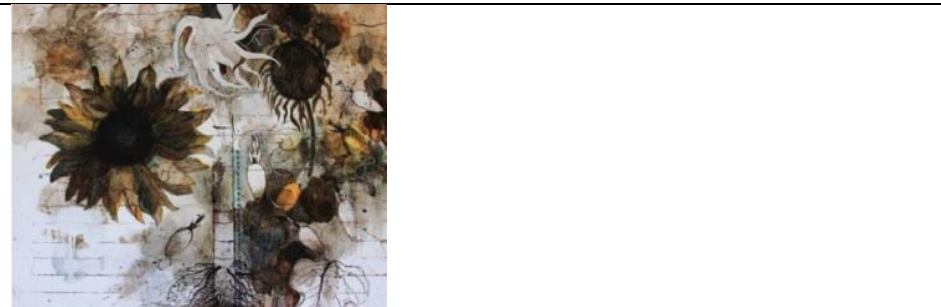 & $\begin{array}{l}\text { Description: } \\
\text { Artist: Abu Bakar Idris. } \\
\text { Title: Secret Sunflower. } \\
\text { Medium: mixed medium. } \\
\text { Size: } 104 \mathrm{~cm} \text { x } 112 \mathrm{~cm} . \\
\text { Year: } 2008\end{array}$ \\
\hline $\begin{array}{l}\text { Sample D } \\
\text { Picture Source : } \\
\text { http://galerichandan.com/wp- } \\
\text { content/uploads/2013/09/rahsia bunga matahari.jpg }\end{array}$ & $\begin{array}{l}\text { Analysis: Painting shows } 2 \\
\text { clear sunflowers, and } 3 \text { faint } \\
\text { sunflowers. There are } 7 \\
\text { randomly scattered flowers } \\
\text { buds to the right of the cats. } \\
\text { The use of dark hot colors } \\
\text { gives the illusion of decays. }\end{array}$ \\
\hline & $\begin{array}{l}\text { Interpretation: The artist } \\
\text { appreciates the motif of } \\
\text { sunflower as a medium used } \\
\text { in herbal medicine that } \\
\text { benefits health such as } \\
\text { headache, toothache, malaria, } \\
\text { measles and so on. }\end{array}$ \\
\hline & $\begin{array}{l}\text { Assess: The artist successfully } \\
\text { creates visuals and creativity } \\
\text { because they have used the } \\
\text { exact image and title. The role } \\
\text { of studying the benefits of } \\
\text { natural plants to find a cure is } \\
\text { an activity that needs to be } \\
\text { preserve. }\end{array}$ \\
\hline
\end{tabular}

Figure 4: Data analysis of Sample D Feldman' Art Critics System

Description:

Artist: Jalaini Abu Hassan

Title: Spring

Medium: acrylic

Size: $138 \mathrm{~cm}$ x $138 \mathrm{~cm}$

Year: 2016 


\begin{tabular}{|c|c|}
\hline \multirow{3}{*}{$\begin{array}{l}\text { Picture Source : } \\
\text { https://www.nst.com.my/news/2016/10/184501/jai- } \\
\text { ho-artist-jai-abu-hassan-romances-landscape-his- } \\
\text { latest-exhibition }\end{array}$} & $\begin{array}{l}\text { Analysis: There are } 2 \text { banana } \\
\text { trees on the left side of the } \\
\text { painting and are balanced with } \\
\text { some wilted banana trees. } \\
\text { Water images in the form of } \\
\text { springs emerge through the } \\
\text { middle of the bottom of the } \\
\text { painting. }\end{array}$ \\
\hline & $\begin{array}{l}\text { Interpretation: The spring is a } \\
\text { natural state where } \\
\text { groundwater flows out of the } \\
\text { earth's to the ground. The work } \\
\text { titled The spring brings a } \\
\text { glimpse of the beauty of local } \\
\text { nature landscape paintings. }\end{array}$ \\
\hline & $\begin{array}{l}\text { Assess: The quality of these } \\
\text { landscapes is so harmonious. } \\
\text { This work is seen in terms of } \\
\text { safe landscape values and as a } \\
\text { whole the work is successful } \\
\text { and genuine. }\end{array}$ \\
\hline
\end{tabular}

Finding and Discussion

Figure 5: Data analysis of Sample E.

Environmental motifs are widely used in paintings in Malaysia. Through this study, the researcher could record six types of motifs from the environment and collected through five samples. The motifs are flora and fauna such as fish, sunflower, banana trees and water springs. The work of mother and children with origami bird by Chuah Thean Theng illustrates the experience of visual arts exploitation closely related to Malay culture. The intimacy of batik with Malay custom and culture is so unique, its fresh motifs and preserved meaning. The work of batik Mother and children with origami bird is one of the best samples that use batik as a method in completing the transformation of space. Formalistic and aesthetic based on three out of the five samples successfully produced works that incorporate cultural features and responses to a holistic environment. Among them are the samples of $A, B$ and $C$. These three samples of this experiment have strengths in the aspects the quality of the medium and the uniqueness of the ideas rendered so superior to the aura and the atmosphere of the people who are in the field. These samples have succeeded in creating a cultural event around its homeland for the 60's until early 2000.

Experimental samples $\mathrm{A}, \mathrm{B}$ and $\mathrm{C}$ are high impact texts in generating unambiguous images. The art scene is often surrounded by more challenging environmental factors, especially in paradoxical significance. The visualization of painting, content or visual context requires knowledge, recorded through a detailed analysis study. Understanding the visual language is increasingly in term of artistic aspect but raises a logical problem in organizing the cultural and environmental significance (Feldman,1982) 


\section{Conclusion}

The power of the paintings of emphasizing cultural characteristic along with the environment is a satisfaction in its creation (Muliyadi Mahamood, 1995). The continuity of knowledge and understanding of grasp, ideas, philosophy, materials, and techniques is the basis for embodying Malay looks in the production of contemporary paintings. Painting production often reflects on the minds of artists, who bring sincere views; the actual view should be highlighted by the response to environmental change. As believed by Shahariah Mohamed Roshdi (2016) the work of art is universal and free in term of material and ideology as long it has value in aesthetic and having its own content to be conveyed to the public.

Adapting the art of using different mediums as well as object applications as symbols, pluralism, leaving the imbalance implications in the visual arts publication in Malaysia. Ahmad Rashidi Hasan and Abd Rasid Ismail (2016) mention that the imbalance in the aspect of publishing requires detailed appreciation which can provide an in-depth picture of a discovery. Indirectly as a record of development for future generations. The findings and interpretations recorded will stimulate interest among researchers, scholars and art enthusiasts who are exploring the development of contemporary paintings in Malaysia.

\section{References}

Ismail, A. R. (2014). Alam Sebagai Motif Kraftangan Fabrik Melayu Tradisi. UiTM Press: Perpustakaan Negara Malaysia

Hasan, A. R. \& Ismail, A. R. (2016). A Brief History of Art. UiTM Press: Perpustakaan Negara Malaysia

Andaya, B. W. (1983). Sejarah Malaysia, Palgrave Macmillan

Azian, T. (2009). National Culture Congress, The Impact to the Malaysian Artist Artwork. Retrieved from http://penulisansenihalus.blogspot.my/2009/04/national-culture-congress-impact-to.html

Feldman, E.B. (1982). Varieties of visual experience. Englewood Cliffs, NJ: Prentice Hall.

Feldman, E.B. (1994). Practical art criticism. New Jersey: Prentice-Hall,Inc

Liz Price. (2014,Mar,22). Gua Badak:Cave Art From the Past. Retrieved from The Star Online Website: https://www.thestar.com.my/travel/malaysia/2014/03/22/gua-badak-cave-art-from-the-past/

Mahamood, M. (2004). Seni Lukis Moden Malaysia (era perintis hingga era pluralis 1930-1980) Kuala Lumpur: Utusan Publication \& Distributors SDN BHD

Mahamood, M. (1995). SeniLukis Dalam Peristiwa. Kuala Lumpur: Dewan Bahasa \& Pustaka 
INTERNATIONAL JOURNAL OF ACADEMIC RESEARCH IN BUSINESS AND SOCIAL SCIENCES

Vol. 8, No. 11, Nov, 2018, E-ISSN: 2222-6990 (C) 2018 HRMARS

Subramaniam, M., Hanafi, J., Putih, A. T. (2016). Teaching For Art Criticism: Incorporating Feldman's Critical Analysis Learning Model In Students' Studio Practice. Retrieved from Institute of Education Science Website: https://eric.ed.gov/?id=EJ1086252

Piyadasa, R. (1981). Pengolahan Landskap Tempatan Dalam Seni Moden Malaysia 1930-1981. Kuala Lumpur: Muzium Seni Negara

Ragan, R. (2005). Art Talk Fourth Edition. New York: Glencoe Mc Graw-Hill

Shahir, S. (2008). MATAHATI-For Your Pleasure: Signifikasi Catan di Malaysia? Retrieved from Wacana Seni Journal of Arts Discourse Website :http://wacanaseni.usm.my/w_j_7.htm

Abdullah, S. (2012,December,27). The Environment as a Theme in Malaysian Art. Retrieved from https://ejournal.um.edu.my/index.php/jati/article/view/5958

Roshdi, S. M., Khalid, M. H. M. \& Ismail, A. R. (2016). Artistik Rhiz: Seni Rupa Kontemporari Malaysia. 3rd International Colloquium 2016, Fakulti Seni Lukis \& Seni Reka, Universiti Teknologi MARA Melaka.

Sabapathy, T.K. \& Piyadasa, R. (1983). Modern Artist of Malaysia. Kuala Lumpur: Dewan Bahasa Pustaka

\section{Corresponding Author}

Shahariah binti Mohamed Roshdi

Email: shahariahroshdi@melaka.uitm.edu.my

Faculty of Art and Design

MARA University of Technology

Alor Gajah Campus

Jalan Lendu, 78000 